\title{
Determinants of a firm's likelihood to innovate and intensity of innovation in the Brazilian food industry
}

\author{
José E.O. Cabral ${ }^{1}$ \& W. Bruce Traill ${ }^{2}$ \\ ${ }^{1}$ EMBRAPA (Brazilian Agricultural Research Company); Rua Dra Sara Mesquita, 2270 Pici, 60511-110 Fortaleza-CE, Brazil; \\ Tel.+55 (0)85 2991953; Fax: +55 (0)85 2991833; E-mail: ednilson@cnpat.embrapa.br \\ ${ }^{2}$ Department of Agricultural and Food Economics; The University of Reading, 4 Earley Gate, Whiteknights Road, Reading, \\ RG6 6AR, United Kingdom; Tel. +44 (0)118 9318389; Fax. +44 (0)118 9756467; E-mail: w.b.traill@reading.ac.uk
}

\begin{abstract}
This paper defines the relative role of firms' characteristics on both their likelihood to innovate and the intensity of innovation (innovative outputs). Using Christensen's $(1995 ; 1996)$ and Teece's (1986) proposals for analysing assets (resources and capabilities) and inter-asset linkages in order to produce and commercially exploit technological innovation, a conceptual framework is defined suitable to identify the variables affecting the probability of a firm to innovate and those affecting a greater count of innovations, once the firm has decided to innovate.

Thus, a "double-hurdle" approach involving censored and truncated models was applied. The findings confirm that firms innovative assets investment in external technology, investment in $\mathrm{R} \& \mathrm{D}$, and external alliances, alongside firm size are the significant variables in determining firms' likelihood to innovate, whereas external alliances, firm size and market orientation are related to intensity to innovate in the Brazilian Food Industry.
\end{abstract}

Key words: food industry, economics of innovation, Brazil, innovative assets, complementary assets

\section{Introduction}

This paper aims to define the relative role of firms' characteristics on both their likelihood to innovate and the intensity of innovation (innovative outputs). Specifically, this refers to the identification of which innovative and complementary assets, when combined in a multivariate framework, are firstly statistically significant in distinguishing innovating from non-innovating firms in the Brazilian Food Industry (BFI), and secondly in distinguishing more from less innovating firms.

\section{Innovative and complementary assets and technological innovation in the food industry}

Christensen`s (1995; 1996) and Teece's (1986) proposals for analysing assets (resources and capabilities) and interasset linkages in order to produce and commercially exploit technological innovation define the conceptual framework depicted in figure 1: both innovative and complementary assets, and their interplay are recognized as major determinants of technological innovation.

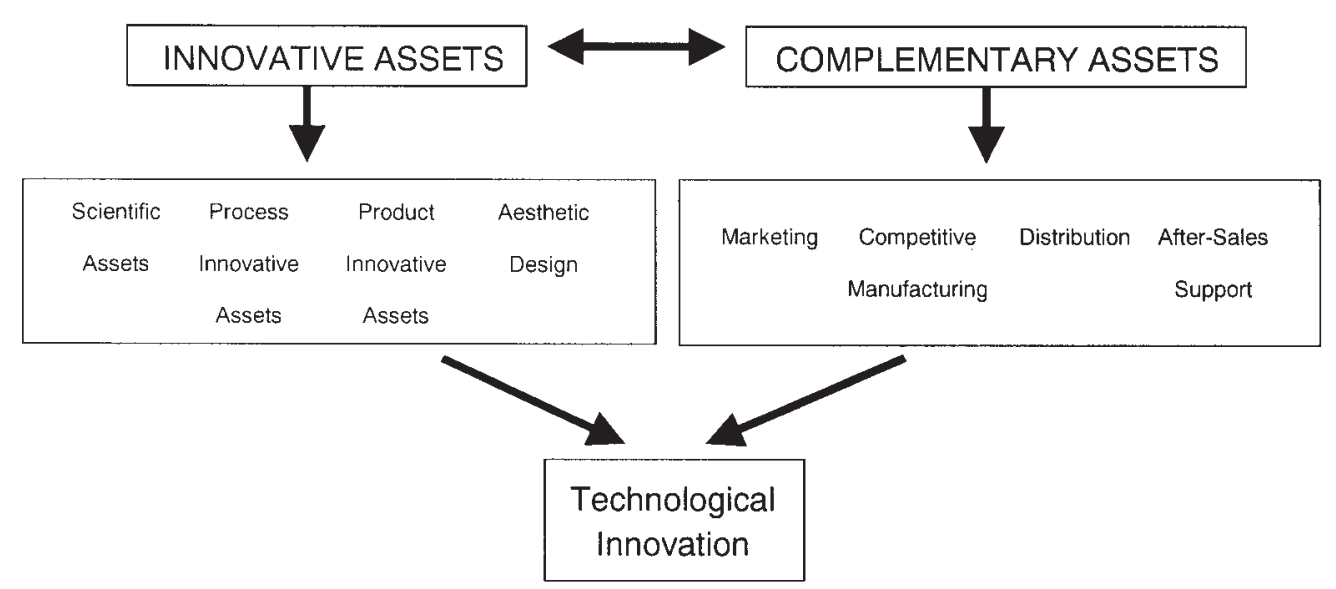

Figure 1. 
In his framework, Christensen (1995; p.730) points 'to the importance of having access to relevant innovative assets in order to secure the very production of technological innovation'. The basic point of this approach is that technological innovation requires not only the application of R\&D effort, but also (and sometimes excluding R\&D) the application of different types of innovative assets for innovation development. Christensen (1996; p.197) claims that $R \& D$ is a limited concept to indicate the full spectrum of innovative assets needed for technological innovation. In general, the R\&D concept within firms is restricted to 'what goes on in the R\&D or engineering department of the firm' and, 'in its narrow statistical meaning, grossly underestimates or even neglects important parts of technological development efforts' (p.196).

Hence, the innovative assets, contemplated in this approach, encompass the resources and capabilities 'required for producing new or improved technologies and ultimately new products and processes' (Christensen, 1996; p.197). They are divided into four generic groups: scientific research assets, process innovative assets, product innovative application assets and aesthetic design assets. They were defined by Christensen (1996; p.198) as below:

a. Scientific research assets (corresponding to the R in R\&D) involve both basic research of a pre-competitive nature and applied or industrial research that provide direct inputs into process development and new product application.

b. Process innovative assets both comprise resources and capabilities for "hardware" process innovation, and the more "systemic" capacity involved in developing the production system, the inbound and outbound logistics, quality control, and plant layout.

c. Product innovative application assets are the resources and capabilities required for product development (apart from the possibly scientific research and aesthetic design): product engineering, instrumentation and software development.

d. Aesthetic design assets are mostly thought of as a part of the marketing attributes of the product, but aesthetic design is also a distinct part of, or has a close physical relationship to, the product which makes it a bridge between technical and functional features of the product and marketing attributes.

These categories of innovative assets represent a more comprehensive model for understanding the multidimensional base of the innovative process within firms. Whereas in some firms this process is more concentrated on formalized research, in others diverse forms of internal learning or aesthetic design are dominant. However, most firms, generally, deploy more than one category of innovative asset. Christensen $(1995 ; 1996)$ borrowed from transaction cost economics the analysis of inter-asset specificity to characterize the degree to which innovative activities based on one asset depend on other asset(s). The degree of interasset specificity is low if the innovative activity relates exclusively to one asset. It is high if there is connection of two or more assets as, for instance, when product innovation demands major alteration in the production process and/or previously activated $R \& D$. In this paper, three categories of innovative assets are analysed: 1) investment in $R \& D, 2$ ) external alliances aiming to develop innovation, and 3 ) investment in technologies externally developed.

Given the relatively low industrial level of R\&D expenditures in relation to sales ratio, compared to other industries, $R \& D$ is generally not considered as a very important asset to innovations in the food industry. However, the emergence of new "technological paradigms" for food processing has stimulated food firms to carry out in-house R\&D and/or contract out $R \& D$ from independent firms, thus increasing $\mathrm{R} \& \mathrm{D}$ expenditures and technological capabilities. Moreover, in general terms, Cohen and Levinthal (1989) claimed a dual role for $\mathrm{R} \& \mathrm{D}$, i.e., it is not only important to innovate but it also improves the firms' capacity to assimilate and exploit new knowledge. Although, not very important in the case of capital embodied innovations, $R \& D$ is essential in the cases of 'disembodied innovations that require more complementary internal effort, and more pre-existing expertise in an area' (Cohen and Levinthal, p.594). Hence, since innovative activity, in any form, demands firms' competence, $R \& D$ activity plays a very important role in helping to build up the necessary competence to develop, assimilate and adapt technologies.

Consequently, theory does not provide unambiguous prior expectations about the role of R\&D in a firm's innovative outputs in the food industry. However, whereas previous empirical works have found a strong relationship between $R \& D$ expenditures and innovative output for industries in general, in the food industry this has not been the case (e.g., Connor et al., 1985). In turn, given the proposals that $R \& D$ effort increases a firm's innovative competence, it is predicted that a significant relationship exists between R\&D expenditures and a firm's innovative intensity. Furthermore, since a huge part of food firms' $R \& D$ expenditure is allocated to contracted out R\&D activity, a significant relationship between external alliances, that aim to develop innovation and innovative outputs, is predicted.

In terms of level of investment in technologies externally developed has been suggested (e.g., Connor et al., 1985; Galizzi and Venturini, 1996) that especially process innovations originating from outside the food industry explain the technical efficiency and the high level of productivity growth observed in the food industry. 
Thus, the following hypotheses related to the relationship between innovative assets and innovative outputs are formulated:

- Hypothesis 1. Given the predominance of both capital embodied and incremental innovations in the BFI, R\&D expenditure is not a strong predictor of a firm's likelihood to innovate.

- Hypothesis 2. Given that R\&D activity increases a firm's capacity to innovate, $R \& D$ expenditure is predicted as strongly related to a firm's innovative intensity.

- Hypothesis 3. Given the high level of outsourced R\&D in the food industry, external alliances aiming to develop innovation are a strong predictor of innovative outputs in food firms.

- Hypothesis 4. The level of investment in technologies externally developed will be statistically significant in the likelihood to innovate and in the intensity of innovations in the food industry.

Christensen's framework is concerned with innovative assets required to produce a technological innovation. However, the innovative activity is only completed when the innovation is successfully commercialised. To achieve this, innovating firms also need complementary assets that support the innovative activity and secure to them the benefits of innovation (Teece, 1986). These complementary assets are related with functional areas of firms such as marketing, competitive manufacturing, distribution and after-sales support. They can be matched internally or contracted out, typically downstream in the chain.

Thus, studies have tried to define the relative role of selected supporting assets on innovative outputs. Related variables include firms' marketing orientation and functions in the chain and product chains of firms (levels of vertical integration and horizontal diversification, respectively $)^{1}$. In terms of marketing orientation, the indicators selected include advertising and exports influence on innovations ${ }^{2}$. Advertising is considered a very important marketing activity supporting innovation in the food industry, mainly in the case of product innovation. In addition, Galizzi and Venturini (1996; p.142) found that its importance also depends on the customer targeted. The importance of exports to innovations is also relative, depending upon, among other things, the size and growth potential of firms' domestic market. In the case of the overall Brazilian manufacturing industry, Braga and Wilmore (1991; p.429) found that exports positively influence technological efforts. However, the authors stressed that the result might vary from one industry to another.

With regards to vertical integration, in general it is expected that a higher level of integration favours a higher level of innovative output. However, this relationship is mediated by a series of other characteristics, such as degree of innovative inter-asset specificity, kind of innovation (autonomous or systemic ${ }^{3}$ ), and level of technology appropriability. The proposals are that vertical integration is more feasible when there is high inter-asset specificity, predominant systemic innovations, and low levels of appropriability. In turn, considering the prevalent aspects of innovations in the food industry, such as incremental, process, and new only to the innovating firm (imitation), one can consider them as autonomous and presenting weak appropriability. On the other hand, one can deduce that while autonomous innovations favour decentralization, weak appropriability favours integration. Thus, one cannot provide unambiguous prior expectations about the direction of the relationship between innovative output and vertical integration. However, as the general level of inter-asset specificity in the industry is low, the relationship between vertical integration and innovative output should be weak. In turn, reasons are given (e.g., Teece, 1996; p.203) to suggest that the innovative performance might also be impacted by the scope of firms. However, it is also posited (e.g., Nelson, 1959) that the horizontal diversification effect on innovative output should be more significant when associated to "basic" research. This clearly is not the case in the food industry. From the propositions above, the following hypotheses are formulated related to the relationship between complementary assets and innovative outputs:

- Hypothesis 5. Given the predominance of process innovations in the food industry, advertising level is not a strong predictor of a firm's likelihood to innovate.

- Hypothesis 6. Given that the intensity of innovations is associated with a larger proportion of product innovations, advertising level is expected to be significantly associated with a firm's innovative intensity.

- Hypothesis 7. Given the size and growth potential of the Brazilian food market, exports are not significantly related to a firm's innovative outputs (likelihood and intensity).

- Hypothesis 8. Higher levels of vertical integration and horizontal diversification are not significantly associated with a firm's likelihood and intensity to innovate.

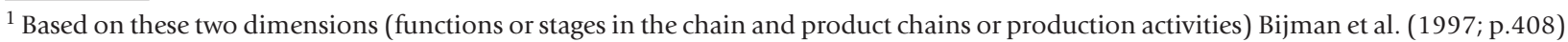
present a typology of food processing firms.

${ }^{2}$ It is recognised that this is a limited number of indicators to measure the construct. Kohli et al. (1993), for instance, propose a measure of market orientation (MARKOR) comprised of thirty-two indicators (scale items).

${ }^{3}$ See Teece (1998; p.268) about these two kinds of innovations.
} 
Now the effect of complementary variables will be considered. The objective is to evaluate the effect of complementary assets on innovations, controlling their influences through other conventionally considered determinants of innovative activity. They are firm size and age.

In terms of firm size, it has been one of the most tested explanatory variables in studies about the determinants of innovation. Both theoretical reasoning and empirical results for its relationship with innovation did not reveal conclusive results. The latter has shown that this undefined result is due to the fact that the relationship of size with innovation depends on the empirical context, industry or sector. There are conditions and industries where the innovative efficiency is a prerogative of smaller firms and other conditions and industries where the efficiency in innovation prevails for larger firms. In the case of the food industry the majority of empirical studies has confirmed the hypothesis that larger firms are more innovative, as in the studies of Galizzi and Venturini (1996; p.144)and Huiban and Boushina (1998). The latter authors found that firm size is the strongest determinant of the probability to innovate in the French food industry. They also found that in this industry 'the best situation for innovation seems to be a large firm located in a not highly concentrated market' (p.396). In the case of the Brazilian industry, as a whole, Braga and Wilmore (1991; p.429) also found that size is significantly related to technological efforts although presenting rather low estimated coefficients.

Finally, with regards to firm age it is suggested that accumulated learning favours innovative output. The hypotheses which are correspondent to complementary variables are formulated below.

- Hypothesis 9. Large firms in the food industry are more likely to innovate and to present a greater innovative intensity.

- Hypothesis 10. Older firms present higher likelihood and intensity to innovate.

\section{The data set, method, analytical model and results}

The empirical basis for achieving the paper's objective is a data set assembled from a survey focusing upon innovative activity in the BFI. This survey was designed to assemble a broad description of the firms' organizational characteristics and innovative activity in the BFI.

The survey measured innovation through a direct proxy, which has been considered as providing a more reliable account of the innovative intensity, within firms and across industries, than the use of R\&D and patents ${ }^{4}$. In achieving this, innovation was defined as the first commercial transaction of an idea involving a new or improved product or process of production (Galizzi and Venturini, 1996; p.7). Hence, technological innovation involves shifts in the process of production (process innovation) or the improvement or creation of a new consumer or capital good (product innovation). In some studies, "first" has been qualified as either new to the world or new to the country at issue (e.g., Pavitt, 1984; p.344), while in other studies new has been qualified as new for the world, country or firm (e.g., Cesaratto and Mangano, 1993; p.115; Christensen et al., 1996; p.8; Myers and Marquis, 1969; p.3). The survey followed these trends measuring innovation in the "broad" sense of new to the world, country or firm ${ }^{5}$. Accordingly, the direct indicator chosen to use in the survey was 'innovation count', that means the number of technological innovations generated and/or acquired by a surveyed firm in a previously defined period of time. Researchers have identified these innovations, among others, by asking the firms' managers to list the innovations implemented in their firms, or posing the same question to technical experts and firm insiders regarding the innovations implemented in some line of business. The survey mixed the two approaches: first, firms were asked to list their innovations in the research period; second, the list was submitted to the analysis of a group of food technology experts (three), from EMBRAPA - Brazilian Agricultural Research Company. This committee assessed not only whether the indicated innovation really should be considered a technological innovation, but also assessed the responses about the qualitative characteristics of the

\footnotetext{
${ }^{4}$ Patel and Pavitt (1995) and Santarelli and Piergiovanni (1996) present an extensive list of shortcomings and drawbacks of innovation indicators. Cabral (1999) summarizes the main shortcomings of patents and R\&D.

${ }^{5}$ This broad sense was applied based on the premise that technological innovations, at world level in the food industry, are not a very common event. In addition, as Rosegger (1996; p.172) states, 'a product or process hardly ever remains unchanged as it is diffused; therefore, "firsts" abound even after an original innovation has occurred, and many of these turn out to be at least as significant, technically and economically, as the basic innovator's contribution'. In turn, Kline and Rosenberg (1986; p.283) suggest that '...most important innovations go through rather drastic changes over their lifetimes - changes that may, and often do, totally transform their economic significance'. Finally, one important reason for this choice was to follow other international studies and compare these results. Thus, this work is considering the processes of innovation and imitation in Schumpeterian terms.
} 
innovations in terms of complexity, type, and newness (e.g., radical or incremental, product or process). The main result achieved was the homogenisation of the qualitative responses.

In order to carry out the survey, the food processing industry was defined based on the official industrial classification approved by the Brazilian Government ${ }^{6}$. In this classification, the food industry is one of the twenty-one two-digit industry groups that comprise the country's manufacturing industry and it is distinguished by nine food sectors (three-digit level). From this definition, the list of firms in the food industry was taken as the basis for sample selection. Hence, 38,916 firms ${ }^{7}$ in the food industry constituted the initial population to base the sample selection. As some questions were considered as very new to firms and demanding a very organized internal file system, the smallest ones (lesser than five employees) were excluded from this population basis. Thus, the definitive population basis was composed of 19,045 firms or $48.9 \%$ of the industry's total, but corresponding to $92.4 \%$ of the employment, $96.2 \%$ of the payroll, $97.9 \%$ of the output and $97.6 \%$ of the value-added ${ }^{8}$.

From the population basis, a relatively large stratified random sample of 1,000 firms was selected. The stratification was undertaken by economic activity (food three-digit manufacturing line of business), firm size (number of employees) and geographical region of Brazil. These firms were asked to fill out a questionnaire (Appendix 1) about their organizational characteristics and also their innovative, strategic and managerial activities, during the three year period of 1994 to 1996. This period of three years was defined due to yearly fluctuations in industries' and firms' innovative activities and to take into account the fact that technological innovations may not be a very steady event at the firm level. Actually, the longer the period the better the information, especially for longitudinal studies. The three year period began in 1994 as this was the starting point of a large restructuring of the Brazilian economy. 248 firms responded to the questionnaire (24.8\%). From these, 167 (67.4\%) indicates that they had not introduced innovations in the period, 77 firms (31.0\%) that they had introduced 233 innovations, four firms (1.6\%) have not responded to this question. Six firms were excluded from this research, three because they did not correspond to the definition given of food processing firms (two are exclusively in catering and one is exclusively in the wholesaler sector) and three because they did not respond to the letter asking for complementary and clarifying information. From the 233 innovations, the committee of experts excluded 95 because they were considered as not conforming to the definition of technological innovation. They referred to organizational innovations or to adaptive changes in manufacturing (minor change in the production process or simple replacement of old equipment), or to simple product variations (changes of shape, label and/or packaging design). Thus, of the 242 firms, 66 innovating firms, and 138 innovations were included in the following analysis. The distribution of these figures by food sector, at three-digit level, is presented in table 1.

The analytical model should be suitable to identify the variables affecting the probability of a firm to innovate and those affecting a greater count of innovations, once the firm has decided to innovate. A model used to account for this double information has been the Tobit regression model. But, as there is no reason to expect that the same variables affect both decisions (as in the theoretical propositions above), the use of two analytical models or the application of the "double-hurdle" approach has been usually suggested (e.g., Burton et al., 1994; Goetz, 1995; Wakelin, 1998). The first should be a censored model where the dependent variable, likelihood to innovate, is defined as the probability of the ${ }_{\mathrm{i}}$ th firm deciding to innovate (coded as: $\mathrm{LI}_{\mathrm{i}}=1$ if the $\mathrm{i}^{\text {th }}$ food firm innovated; or $\mathrm{LI}_{\mathrm{i}}=0$ if the $\mathrm{i}^{\text {th }}$ firm did not innovate). The second should be a truncated model, where the dependent variable, intensity of innovative output, is observed only if it takes a value greater than zero. It is coded as $\mathrm{PI}_{\mathrm{i}}>0$, with $\mathrm{PI}_{\mathrm{i}}$ standing for firm's number of innovations. With regards to innovative assets, the indicators include? $\mathrm{R} \& \mathrm{D}$ expenditure (redmo), measured as a proportion of a firm's turnover according to one of the seven classes given in the survey questionnaire, which is the usual measure of R\&D intensity. External alliances (altot) measured through number of agreements, with private companies and public agencies and universities, to develop technological

\footnotetext{
${ }^{6}$ FIBGE - Brazilian Institute of Geography and Statistics: Resolucao do Presidente No R.PR. 054/94. This classification is very similar to NACE, English SIC and USA 1992 Standard Industrial Classification Manual.

${ }^{7}$ From 43,034 establishments. This small difference confirms that most food processing firms develop production activities in just one place. (see also Connor and Schiek, 1997; p.65).

${ }^{8}$ Source: FIBGE - Censo Industrial 1985. Actually, these shares refer to establishments with more than five employees, due to the lack of this information by firms. In addition, it is noted that the choice of this year (1985) was due to the fact that it represented the last quinquenal (every fifth year) industrial census by FIBGE. From this year on, the FIBGE passed to publish an annual industrial research with the information aggregated at a greater level.

${ }^{9}$ For further information on the survey questions and indicators measurement, see the questionnaire in Cabral (1999).
} 
Table 1. Food sectors and innovativeness.

\begin{tabular}{|c|c|c|c|c|c|c|c|c|}
\hline Sector & $\begin{array}{l}\text { Surveyed } \\
\text { (Count) }\end{array}$ & $\begin{array}{l}\text { Firms } \\
\qquad(\% 0 T F S)\end{array}$ & $\begin{array}{l}\text { Innovating } \\
\text { (Count) }\end{array}$ & $\begin{array}{l}\text { g Firms } \\
\text { (\%OTIF) }\end{array}$ & (Index) & $\begin{array}{l}\text { Innovati } \\
\text { (Count) }\end{array}$ & (\%OTIF) & (Index) \\
\hline Meat and Fish & 32 & 13.2 & 8 & 12.1 & .92 & 18 & 13.1 & .99 \\
\hline Fruits and Vegetables & 19 & 7.9 & 7 & 10.6 & 1.34 & 22 & 15.9 & 2.01 \\
\hline Fat and Oils & 10 & 4.1 & 2 & 3.0 & .73 & 2 & 1.5 & .36 \\
\hline Dairy & 27 & 11.2 & 6 & 9.1 & .81 & 10 & 7.2 & .64 \\
\hline Grains and Animal Feed & 53 & 21.9 & 9 & 13.7 & .63 & 16 & 11.6 & .53 \\
\hline Sugar & 13 & 5.4 & 5 & 7.6 & 1.41 & 18 & 13.1 & 2.43 \\
\hline Coffee & 9 & 3.7 & 2 & 3.0 & .81 & 5 & 3.6 & .97 \\
\hline Miscellaneous-Cocoa-Bakery & 57 & 23.5 & 20 & 30.3 & 1.29 & 34 & 24.6 & 1.05 \\
\hline Others & 22 & 9.1 & 7 & 10.6 & 1.16 & 13 & 9.4 & 1.03 \\
\hline Total & 242 & 100 & 66 & 100 & - & 138 & 100 & - \\
\hline
\end{tabular}

OTFS = Share of total firms surveyed; OTIF = Share of total innovating firms; 0 TI = Share of total innovations; Index=0TIF/OTFS or OTI/OTFS. The index greater than one means that the sector presents a performance in terms of innovating firms or innovations above the overall industry's mean.

Source: Survey

innovations that each firm carried out during the research period. Technological innovation activities (tecmo), excepting $R \& D$ expenditures, measured by proportion of a firm's turnover, also from the seven classes in the questionnaire, allocated to acquisition of technology externally developed. The indicators of complementary assets include: Advertising (advmo) measured by the ratio of advertising expenditure over turnover (seven points). Exports (expmo) measured by the scores (also seven points) each firm gave to proportion of turnover generated through exports. Vertical integration (proto) measured by the number of production and distribution stages (food chain) in which each firm participates. Finally, horizontal diversification (atota) measured by the number of food segments (four-digit SIC level) in which each firm produces and commercialises.

The complementary variables, as above, include size and age. In terms of size, the majority of studies have used firms' total employment full-time equivalent. However, some studies (e.g., Scherer, 1965) prefer to use annual sales (turmo) because the theoretical propositions about the positive influence of size on innovative output are mainly based on the availability of financial resources and cash-flow. Hence, and considering that the variables are positively but not perfectly correlated, size will be measured, at the start, by employment (empme). Alternatively, a second equation will be run, with turmo replacing empme. In addition, many related studies have shown that innovative output increases with large sized-firm, but only until a particular threshold. Thus, they have concluded that there is non-linearity in the relationship. Hence, a quadratic specification for the size variables (empme $e^{2}$ and turmo ${ }^{2}$ ) shall be included in the models to test for possible non-linearity. Finally, age (fiold) will be measured by number of years since the firm's establishment until the survey year 1997.

The functional econometric form for the first model, therefore, is:

$\mathrm{LIi}=\mathrm{f}($ redmo, altot, tecmo, advmo, expmo, proto, atota, empme, fiold $)$

As above, the dependent variable is of the binary type, taking the values of zero or unity, with the former being predominant. The specification should take the form of a censored model, of which the Logit regression model is one of the well-established procedures.

The functional econometric form for the second model just changes the dependent variable to PIi. It can be written as:

$\mathrm{PIi}=\mathrm{f}($ redmo, altot, tecmo, advmo, expmo, proto, atota, empme, fiold $)$

The results of the parameter estimates for firms' likelihood to innovate and firms' intensity of innovation, in the two models (logit and truncated) are presented in table 2. As expected, given the high correlation coefficient between them, the variables empme and turmo presented similar significance and direction of the relationships, with a slightly higher predictive significance for the model with empme. Thus, only the results with this variable will be reported here, a discussion of which will follow below. 
Table 2. Parameter estimates for innovative likelihood and intensity.

\begin{tabular}{|c|c|c|c|c|c|c|c|c|}
\hline \multirow{3}{*}{$\begin{array}{l}\text { Explanatory Variables } \\
\text { Redmo }\end{array}$} & \multicolumn{4}{|c|}{ Logit Model } & \multicolumn{4}{|c|}{ Truncated Model } \\
\hline & \multicolumn{2}{|c|}{ Equation 1} & \multicolumn{2}{|c|}{ Equation 2} & \multicolumn{2}{|c|}{ Equation 3} & \multicolumn{2}{|c|}{ Equation 4} \\
\hline & 0.47 & $(0.24)^{* *}$ & 0.47 & $(0.24)^{* *}$ & -0.14 & $(0.26)$ & -0.20 & $(0.20)$ \\
\hline Altot & 0.38 & $(0.17)^{\star *}$ & 0.39 & $(0.18)^{* *}$ & 0.32 & $(0.17)^{*}$ & 0.36 & $(0.13)^{* * *}$ \\
\hline Tecmo & 1.10 & $(0.26)^{* * *}$ & 1.10 & $(0.26)^{* * *}$ & -0.23 & $(0.27)$ & -0.84 & $(0.20)$ \\
\hline Advmo & 0.271 & $(0.18)$ & 0.27 & $(0.18)$ & 0.44 & $(0.18)^{* *}$ & 0.32 & $(0.13)^{* *}$ \\
\hline Expmo & -0.20 & $(0.22)$ & -0.21 & $(0.22)$ & 0.10 & $(0.23)$ & -0.16 & $(0.18)$ \\
\hline Proto & 0.25 & $(0.25)$ & 0.25 & $(0.25)$ & -0.29 & $(0.32)$ & -0.27 & $(0.24)$ \\
\hline Atota & -0.26 & $(0.18)$ & -0.26 & $(0.18)$ & -0.22 & $(0.28)$ & -0.28 & $(0.21)$ \\
\hline Empme & \multirow{2}{*}{\multicolumn{2}{|c|}{$0.0019(0.0007)^{* *}$}} & \multicolumn{2}{|c|}{$0.002(0.0007)^{* * *}$} & \multicolumn{2}{|c|}{$0.00012(0.00007)^{*}$} & \multicolumn{2}{|c|}{$0.0009(0.00018)^{* *}$} \\
\hline Empme $^{2}$ & & & \multicolumn{2}{|c|}{$\begin{array}{l}-.00000005 \\
(0.00000003)^{*}\end{array}$} & & & \multicolumn{2}{|c|}{$\begin{array}{l}-0.000000024 \\
(0.00000006)^{* * *}\end{array}$} \\
\hline Fiold & -0.01 & $(0.01)$ & -0.01 & $(0.01)$ & 0.50 & $(0.11)$ & -0.34 & $(0.86)$ \\
\hline Constant & -4.32 & $(0.84)^{* * *}$ & -4.32 & $(0.84)^{* * *}$ & 1.36 & $(1.30)$ & 1.93 & $(0.93)^{* *}$ \\
\hline Chi Square & \multicolumn{2}{|c|}{$\begin{array}{l}-4.32 \quad(0.04) \\
91.32^{* * *}\end{array}$} & & $91.48^{* * *}$ & & & & \\
\hline Sigma & \multirow{2}{*}{\multicolumn{2}{|c|}{0.51}} & & & 1.61 & $(0.25)^{* * *}$ & 1.28 & $(0.17)^{* * *}$ \\
\hline Nagelkerke $\mathrm{R}^{2}$ & & & \multicolumn{2}{|l|}{0.51} & & & & \\
\hline Number of Observations & \multicolumn{2}{|l|}{202} & \multicolumn{2}{|l|}{202} & \multicolumn{2}{|l|}{62} & \multicolumn{2}{|l|}{62} \\
\hline
\end{tabular}

Standard errors in parentheses. ${ }^{*}, * *, * *$ Significant at $10 \%, 5 \%$ and $1 \%$, respectively.

Table 2 shows that, overall, both models present a set of statistically significant coefficients, in terms of chi-square distribution for logit and sigma for truncated models. The results confirm most of the hypotheses previously formulated, and in particular, that there are important differences between the likelihood to innovate and the intensity of the innovative process, in food firms. The differences will be reported and discussed below, starting with the first model.

The estimated logit model correctly predicts $81 \%$ of the possible outcomes (innovate/no-innovate). The individual influence of explanatory variables follows. The first equation confirms that the incremental nature and predominant external sources of innovations make the investment in technologies externally developed the most significant variable, in a multivariate framework, of the food firms' probability to innovate. Another reason for that is the existence of "redundant technologies" for the industry (see Cabral, 1999). Redundant technology, according to Padberg and Westgren (1979) means that the state of the art in food science and technology offers relevant opportunities for technological innovation in the food industry. In other words, the stock of available technology presents a "surplus" compared with technology in use in the industry. Investment in technologies externally developed, thus, increases by more than three times the odds that a firm innovates ${ }^{10}$. The first equation also confirms the hypothesis that a firm's likelihood to innovate is also related to size. Although this hypothesis was confirmed with high statistical significance $(\rho<0.05)$, the estimated coefficient is rather small.

The R\&D expenditures variable presents a highly significant and relatively expressive coefficient. It is significant at less than $5 \%$ and increases by more than one and a half times the odds that a firm innovates. In addition, the variable regarding a firm's external alliances to carry out innovative activities is also statistically significant. These results suggest the rejection of the hypothesis that R\&D is not a strong predictor for innovation and to accept the hypothesis about the importance of alliances. Thus, they confirm the proposals of an increasing role of outsourced $R \& D$ activities in the innovative process of food firms. In addition, this suggests that although not exclusively dependent on $R \& D$, the innovative activity of food firms may be enhanced with $\mathrm{R} \& \mathrm{D}$ competence.

With regards to the remaining variables in the first equation, all results, except age, confirm the research hypotheses. The level of advertising and the level of functions in the chain (proto) present positive coefficients although not statistically

$\overline{10}$ The antilog of 1.10 is 3.01 . 
significant. Similarly in terms of significance, but in the opposite direction, the levels of exports (expmo), of product chains (atota) and age (fiold) present a negative sign. These results add evidence for the theoretical suggestions that food firms' likelihood to innovate is not significantly determined by complementary assets, in terms of market orientation, vertical integration and horizontal diversification. Despite the changes in demand, Brazilian food firms continue to be predominantly manufacturing oriented.

In turn, the second equation of the logit model included the quadratic term of the size variable $\left(e m p m e^{2}\right)$. As hypothesized, this term presents a negative and significant $(\rho<0.1)$ coefficient. Thus, this confirms that the influence of size is not linear, suggesting that the likelihood to innovate increases with firm size up to a threshold level and then declines, confirming a " $U$ " inverted relationship.

As above, the truncated model is included in the analysis to identify the variables affecting a greater count of innovations once the firm has decided to innovate. The basic premise was that there is no reason to expect that the influences of the variables on the likelihood to innovate and on the innovation intensity are similar. The existence of differences was confirmed by the results. From the logit model, (the first equation), just the variables regarding firms size and alliances present again, in the truncated model (equation three), positive and significant coefficients. In addition, the variable advertising expenditures, as hypothesized, attains statistical significance. This result suggests that firm size, external alliances to undertake research, and market orientation (expmo changes sign from negative to positive, although not significant) increase the intensity of innovations of firms in the food industry.

Finally, the fourth equation reinforces the result that the influence of size on innovative activities is not linear, since the coefficient of empme squared is negative and statistically significant. This provides additional evidence that there is no appreciable effect of scale on innovative activity (see Klevorick et al., 1995; p.786).

\section{Discussion}

The findings show that investment in technology externally developed is a very significant variable related to firms' likelihood to innovate in the BFI, confirming Connor et al. (1985) proposal and Gallizzi and Venturini (1996) findings. Three main aspects explain this influence: the incremental nature and the predominance of capital embodied innovations in the industry and the existence of "redundant" technology. Hence, this is in accordance with the characterization of food firms as "supplier-dominated" in innovative terms. However, this factor is not significant in explaining the intensity of innovations in these firms. In this case, there is much at work to increase the innovative efficiency, such as market orientation and external alliances to develop technology.

The findings also suggest that a firm's R\&D effort is related to the firm's likelihood to innovate, but not to the intensity of innovation. This result is rather surprisingly given previous proposals that whilst a firm can innovate without engaging in $R \& D$, it will increase its competence to innovate when carrying out R\&D (e.g., Cohen and Levinthal, 1989; Connor et al., 1985).

In turn, firm size was confirmed also as a very important determinant of both a firm's likelihood and intensity to innovate. However, in both relationships, the influence of firm size increases up to a threshold and then declines, suggesting an inverted " $U$ " shaped relationship. Similar to the influence of size, the level of outsourced R\&D increases not only the likelihood but also the intensity to innovate. This result means that although small, the link of food firms with private and state institutions of research and development has been very effective in spurring food firms into innovative activity.

With regard to complementary assets, the association was confirmed between market orientation, expressed by one single indicator, advertising expenditures (advmo), with the intensity to innovate. This was expected due to the fact that advertising is related to product innovation, which in turn is related to a higher level of innovative output. The other complementary assets indicators, product chains (horizontal diversification), functions in the chain (vertical integration), exports (expmo) and age (fiold) were not significantly related with either likelihood or intensity. Thus, one possible deductive statement from these results is that specialization in product and in stages of production, and the predominance of domestic market targeting impose more pressure on firms in the BFI to innovate.

\section{Concluding remarks}

These different variables influencing the probability and intensity of the innovative activity of firms in the BFI, in different ways confirm that firms' resources and capabilities might correctly be imputed as the main factors at work in defining the innovative possibilities of any firm in the food industry. In other words, from the incentives and constraints posited by the "context", firms' behaviour further constrains and enhances its innovative trajectory.

This result requires that to define the most useful technology strategy, firms need to identify their technological possibilities and constraints, and boost innovative and complementary assets (resources and capabilities). The best innovative strategy for these firms should be to allocate 
financial resources aiming to update equipment, to learn how to use them effectively, and to strengthen links with upstream suppliers. In addition, considering that the factors investment in external technology, R\&D effort, size, and market orientation explain among one and a half and three times the likelihood or intensity of a food firm to innovate, food firms will be more innovative-effective with a strategy to boost their R\&D efforts and linkages with other firms and/or universities and/or agencies of research, with a view on "inducement mechanisms" arising from technology and market opportunities.

In turn, the result suggests that public policies aiming to spur the innovativeness in the BFI might focus initially on stimulating the development and diffusion of pervasive technologies by the food industry upstream suppliers. Complementary policies should incite food manufacturer firms to allocate resources and to develop absorptive capacity aiming to adopt and adapt technologies - "artefacts" and "knowledge" (embodied and disembodied) - from suppliers, private or public, and competitors. The policies may be direct, through, for instance, financing of food research and subsidies for technology acquisitions, and indirect, through elimination of institutional barriers to innovation, such as custom barriers to import technology. In addition, the result also indicate that encourage firms' linkages for developing innovative projects, firms' achievement of a minimum scale (size), and firms' increase in market orientation, should lead to a higher innovativeness (absolute and relative) in the industry.

\section{Acknowledgements}

The authors are very grateful to two anonymous referees for helpful comments.

\section{References}

Bijman, J.W., R. Van Tulder and M. Van Vliet, 1997. Internationalisation of Dutch Agribusiness and the Organisation of R\&D, in Globalisation of the Food Industry: Policy Implications. Proceedings. (Eds R.J. Loader, S.J. Henson and W.B. Traill), CEFER, Department of Agricultural and Food Economics, The University of Reading, Reading, UK.

Braga, H. and L. Willmore, 1991. Technological imports and technological effort: an analysis of their determinants in Brazilian firms. The Journal of Industrial Economics 39, pp. 421-32.

Burton, M., M. Tomlinson and T. Young, 1994. Consumers' decisions whether or not to purchase meat: a double hurdle analysis of single adult households. Journal of Agricultural Economics 45, pp. 202-12.
Cabral, J.E.O., 1999. Patterns and Determinants of Technological Innovation in the Brazilian Food Industry. PhD. Thesis, The University of Reading (United Kingdom).

Cesaratto, S. and S. Mangano, 1993. Technological profiles and economic performance in the Italian manufacturing sector. Economics of Innovation and New Technology. 2, pp. 237-56.

Christensen, J.F., 1995. Asset profiles for technological innovation. Research Policy 24, pp. 727-45.

Christensen, J.F., 1996. Innovative assets and inter-asset linkagesa resource-based approach to innovation. Economics of Innovation and New Technology 4, pp 193-209.

Christensen, J.L., R. Rama and N. Von Tunzelmann, 1996. Industry Studies of Innovation Using CIS Data: Study on Innovation in the European Food Products and Beverages Industry. EIMSSPRINT, The European Commission, Brussels.

Cohen, W. M. and D. A. Levinthal, 1989. Innovation and learning: the two faces of R\&D. The Economic Journal 99, pp 569-96.

Connor, J.M., R.T. Rogers, B.W. Marion and W.F. Mueller, 1985. The Food Manufacturing Industries. Lexington Books, Lexington, MA.

Connor, J.M. and W.A. Schiek, 1997. Food Processing: An Industrial Powerhouse in Transition. John Wiley \& Sons, New York.

Freeman, C., 1982. The Economics of Industrial Innovation, $2^{\text {nd }}$ edition, Frances Pinter, London.

Galizzi, G. and L. Venturini, 1996. Product Innovation in the Food Industry: Nature, Characteristics and Determinants, in Economics of Innovation: The Case of Food Industry. (Eds G. Galizzi and L. Venturini): Physica-Verlag, Heidelberg.

Goetz, S.J., 1995. Markets, Transaction Costs, and Selectivity Models, in Economic Development in Prices, Products, and People: Analysing Agricultural Markets in Developing Countries. (Ed G.J. Scott), Lynne Riemer Publishers, Inc., Boulder Colorado.

Huiban, J. and Z. Boushina, 1998. Innovation and the quality of labour factor: an empirical investigation in the French food industry. Small Business Economics 10, pp 389-400.

Klevorick, A.K., R.C. Levin, R.R. Nelson and S.G. Winter, 1995. On the sources and significance of interindustry differences in technological opportunities. Research Policy 24, pp.185-205.

Kline, S.J. and N. Rosenberg, 1986. An Overview of Innovation in The Positive Sum Strategy. (Eds S.J. Kline and N. Rosenberg). National Academy Press, Washington, DC.

Kohli, A.K., B.J. Jaworski and A. Kumar, 1993. MARKOR: a measure of market orientation. Journal of Marketing Research. 30, pp.46777.

Myers, S. and D.G. Marquis, 1969. Successful Industrial Innovations: A Study of Factors Underlying Innovation in Selected Firms. National Science Foundation, Washington, DC.

Nelson, R. R, 1959. The simple economics of basic scientific research. Journal of Political Economy 67, pp 297-306.

Padberg, D.I. and R.E. Westgren, 1979. Product competition and consumer behavior in the food industries. American Journal of Agricultural Economics 61, pp. 620-625. 
Patel, P. and K. Pavitt, 1995. Patterns of Technological Activity: Their Measurement and Interpretation in Handbook of the Economics of Innovation and Technological Change. (Ed P. Stoneman), Blackwell, Oxford.

Pavitt, K., 1984. Sectoral patterns of technical change: towards a taxonomy and a theory. Research Policy 13, pp. 343-73.

Rosegger, G., 1996. The Economics of Production and Innovation: An Industrial Perspective. Butterworth-Heinemann Ltd., Oxford.

Santarelli, E. and R. Piergiovanni, 1996. Analyzing literature-based innovation output indicators: the Italian experience. Research Policy 25, pp. 689-711.

Scherer, F. M., 1965. Size of firm, oligopoly, and research: a comment. Canadian Journal of Economics and Political Science 31, pp 256-66.

Teece, D., 1986. Profiting from technological innovation: implications for integration, collaboration, licensing and public policy. Research Policy 15, pp 285-306.

Teece, D., 1988. Technological Change and the Nature of the Firm in Technical Change and Economic Theory. (Eds G. Dosi, C. Freeman, R.R. Nelson, G. Silveberg and L. Soete), Pinter Publishers, London.

Teece, D., 1996. Firm organization, industrial structure, and technological innovation. Journal of Economic Behavior and Organization 31, pp 193-224.

Teece, D., G. Pisano and A. Shuen, 1990. Firm capabilities, resources, and the concept of strategy. University of California, mimeo.

Wakelin, K., 1998. Innovation and export behaviour at the firm level. Research Policy 26, pp 829-841. 


\section{Appendix 1:}

\section{This is a shortened version of the questionnaire used in the research}

\section{A. This part refers to organisational characteristics of your firm}

Firm (Identification Code): .......

Q1. Which food sector, according to FIBGE's three-digit classification, represents your firm's principal activity? (Please tick the appropriate box):

$\begin{array}{ll}\text { I. } & \text { Meat and Fish Processing } \\ \text { II. } & \text { Fruits and Vegetables Processing } \\ \text { III. } & \text { Fat and Oils } \\ \text { IV. } & \text { Dairy } \\ \text { V. } & \text { Grains and Animal Feed Processing } \\ \text { VI. } & \text { Sugar } \\ \text { VII. } & \text { Coffee } \\ \text { VIII. } & \text { Miscellaneous-Confectionery-Bakery } \\ \text { IX. } & \text { Others }\end{array}$

Q2. In which segments of the food industry does your firm develop production activities, according to FIBGE's four-digit classification of the industry? (Please rate the productive activities of your firm in order of importance in terms of volume of production, whereby 1 . represents main activity; 2 the secondary activity; 3 . the third most important activity; and so on until the least important activity, or $\mathrm{O}$ for not applicable):

I. Beef and Pork Slaughtering and Processing

II. Poultry Dressing and Processing

III. Prepared meats: Sausages

IV. Fish Processing

V. Fruit Processing, Canning, and Freezing

VI. Vegetable Processing, Canning, and Freezing

VII. Fruit and Vegetable Juices

VIII. Oils

IX. Refined Oils

$\mathrm{X}$ Vegetable and Animal fats

XI. Fluid Milk

XII. Cheese and Other Milk Products

XIII. Ice Cream

XIV. Rice Milling

XV. Wheat Milling

XVI. Manioc Processing and Flour Production

XVII. Corn Milling and Flour Production

XVIII. Corn Oil

XIX. Animal Feeds

XX. Other Grains Processing

XXI. Raw and Cane Sugar Milling

XXII. Sugar Refining

XXIII. Coffee Milling and Roasting

XXIV. Instant Coffee Production

XXV. Bakery Products 
XXVI. Biscuits

XXVII. Chocolate and Confectionery

XXVIII.Pastas

XXIX. Sauces and Condiments

XXX. Diet Products, Children's Foods, and Conserves

XXXI. Others (Please specify) .......

Q3. Which stages of the food value-added chain is your firm involved in? (Please tick the appropriate box):

I. Production of Raw Materials (Agricultural Sector)

II. Primary Processing (Undifferentiated Products, most of them for Intermediate Demand, e.g., Sugar)

III. Secondary Processing (Differentiated Products, most of them for Final Demand, e.g., Chocolate, Pastas)

IV. Wholesaling

V. Retailing

VI. Catering and Restaurant management

VII. Other (Please specify) .......

Q4. What was your firm's turnover (gross sales), in thousands of "Reais", in 1994 to 1996? (Please tick the appropriate box):

Less than 1,000 (One Million)

1,000 TO 5,000

5,000 TO 10,000

10,000 TO 50,000

50,000 TO 100,000

More than100,000 (One Hundred Million)

1994

1995

1996

Q5. What percentage of the turnover (gross sales) was related to exports? (Please tick the appropriate box):

None $(0 \%)$

Less than $10 \%$

$10 \%$ to $20 \%$

$20 \%$ to $30 \%$

$30 \%$ to $40 \%$

$40 \%$ to $50 \%$

More than $50 \%$

1994

$$
\mid
$$

1995

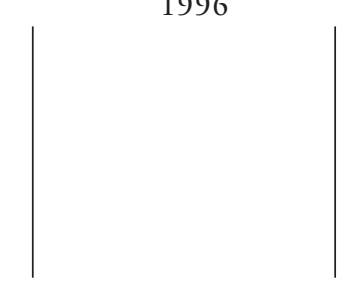

1996

Q6. What percentage of turnover (gross sales) was spent on advertising? (Please tick the appropriate box):

None (0\%)

Less than $1 \%$

$1 \%$ to $2 \%$

$2 \%$ to $3 \%$

$3 \%$ to $4 \%$

$4 \%$ to $5 \%$

More than 5\%
1994

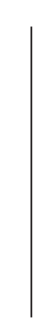

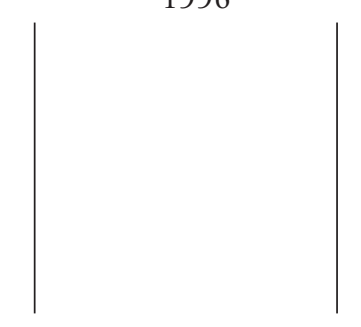


Q7. What percentage of the turnover (gross sales) was spent on R\&D (basic, applied and development)? (Please tick the appropriate box):

1994

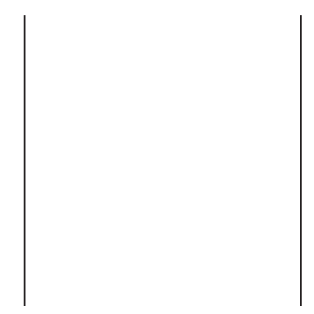

1995

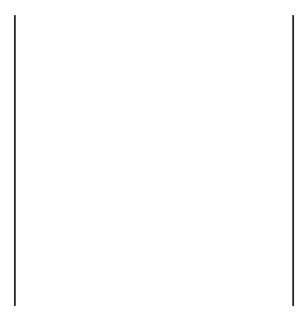

1996

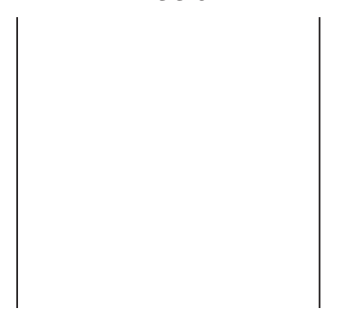

Q8. What percentage of the turnover (gross sales) was spent on other technological innovation activities, such as acquisitions of patents and royalties, technology adaptation, etc.? (Please tick the appropriate box):

1994

None (0\%)

Less than $1 \%$

$1 \%$ to $5 \%$

$5 \%$ to $10 \%$

$10 \%$ to $15 \%$

$15 \%$ to $20 \%$

More than $20 \%$
1995

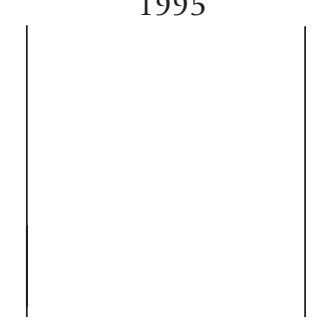

1996

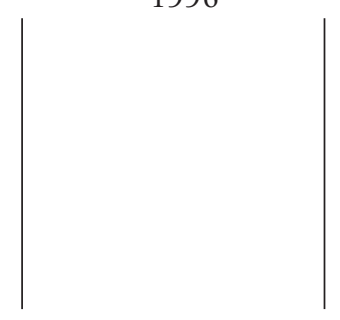

Q9. Does your firm have a formal R\&D department? (If yes, in what year was it established?):

Q10. What was the employment position of your firm in 1994 to 1996? (Indicate the average number of employees in fulltime equivalent per year in the chart below):

1994

Total number of personnel (Full-time employees)

Personnel in R\&D

Ph.D. Researchers

M.Sc. Researchers

B.S. Researchers

Technicians and auxiliary personnel
1995

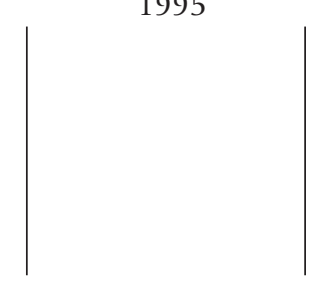

1996

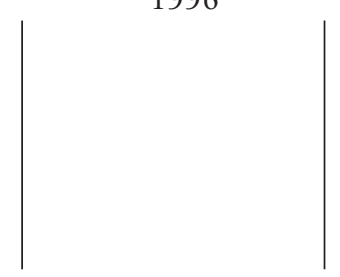

Q11. To what extent has your firm developed the managerial functions below? (Please indicate on a three-point scale, in which 1 represents insignificant, not relevant, or informal, 2 represents an intermediary position, and 3 represents very significant, relevant, or formalised):

Does your firm have a policy regarding technological innovation? Does your firm engage in long-term strategic planning?

Does your firm conduct marketing research?
1

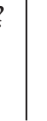

YEAR:

None $(0 \%)$
Less than $0.5 \%$ 
Q12. What external agreements for undertaking R\&D did your firm sign in the period from 1994 to 1996 ? (Please specify the number in the space provided):

Number of agreements with other private firms or independent laboratories to carry out R\&D.

Number of agreements with universities or other non-profit research institutions to carry out R\&D.

Number of R\&D firms or independent laboratories of which your firm has majority ownership (main shareholder).

Number of R\&D firms or independent laboratories of which your firm has minority ownership (main shareholder).
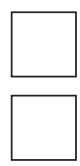

\section{B. This part refers to the characteristics of your firm's innovations}

Q13. Did your firm produce and/or adopt technological innovations in the period from 1994 to 1996 ? (Circle the appropriate answer and follow the instructions).

I. No. (Complete the questionnaire through question 18, and then return the questionnaire in the enclosed envelope)

II.Yes. (Complete questions 19-27, and then return the questionnaire in the enclosed envelope)

Q14. If your answer was YES to question 13, what innovations were implemented by your firm in the period 1994 to 1996 ? (Write in the spaces below the name and the year of each innovation. Please use the additional sheets enclosed if the firm generated/adopted more than ten innovations):

I. Innovation 1

II. Innovation 2

III. Innovation 3

IV. Innovation 4

V. Innovation 5

VI. Innovation 6

VII. Innovation 7

VIII. Innovation 8

IX. Innovation 9

X. Innovation 10
Year:
Year:
Year:
Year:
Year:
Year:
Year:
Year:
Year:
Year:

Q15. What were the major characteristics of each innovation? (Tick the appropriate answer in the chart below):

\section{Characteristics}

The innovation was developed

I. Internally (produced by firm)

II. Externally (purchased/received)

Was the innovation patented?
I. No

II. Yes

Was the innovation developed in collaboration with external institutions?
I. No
II. Yes

Innovations

$\begin{array}{llllllllll}1 & 2 & 3 & 4 & 5 & 6 & 7 & 8 & 9 & 10\end{array}$

ロロロロロロロロロ

$\square \square \square \square \square \square \square \square \square \square$ 
Which institutions participated in the development of the innovation?
I. Customer
II. Private industry
III. Government agencies
IV. Universities
V. Other (please specify)

$$
\begin{array}{llllllllll}
1 & 2 & 3 & 4 & 5 & 6 & 7 & 8 & 9 & 10
\end{array}
$$

The novelty of the innovation was

I. Radical (major)

II. Incremental (minor)

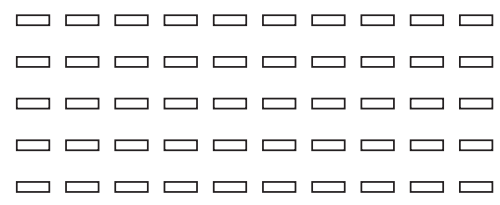

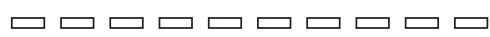

ロロロロロロロロロ

$\square \square \square \square \square \square \square \square \square \square$

ロロロロロロロロロロ

ロロロロロロロロロ

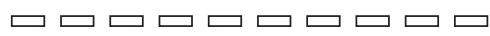

$\square \square \square \square \square \square \square \square \square \square$

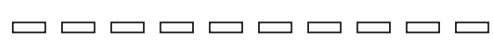

Q16. In what department of the firm was the innovation developed? (Indicate the locus for each innovation in the chart below):

\section{R\&D Department \\ Design department \\ Production department \\ Marketing department \\ Other (please specify)}

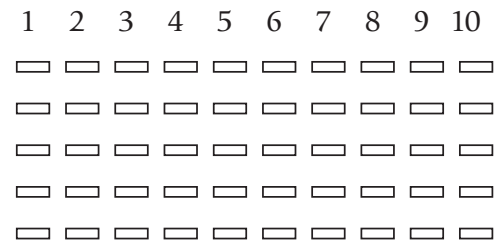

Q17. What factors played the determinant role in the development/adoption of each innovation, i.e., what was/were the main motive (or motives) to innovate? (Please indicate the extent of influence of each factor on each innovation, using a seven-point scale, in which1 represents insignificant or no relevant influence, and 7 represents very significant or very relevant influence):

Innovation 1

Customer's direct request

New technological development (1)

New scientific development (2)

Customer need (3)

To strengthen market position (4)
Extent of INFLUENCE

$$
\begin{aligned}
& \begin{array}{lllllll}
1 & 2 & 3 & 4 & 5 & 6 & 7
\end{array} \\
& \text { ロロロロロロロ }
\end{aligned}
$$

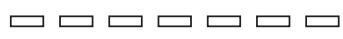

$$
\begin{aligned}
& \square \square \square \square \square \square \square \\
& \text { ロロロロロロ } \\
& \text { ロロロロロ }
\end{aligned}
$$

(1) The generation of the innovation was based on private or public technological knowledge.

(2) The generation of the innovation was based on private or public scientific knowledge.

(3) As perceived by the firm through formal or informal marketing research or another communication channel.

(4) To respond to a competitor's action. 
IMPORTANT: IF YOUR FIRM ADOPTED OR GENERATED MORE THAN TEN INNOVATIONS IN THE PERIOD 1994 TO 1996, PLEASE USE THE ADDITIONAL SHEET ENCLOSED AND PHOTOCOPIES IF NECESSARY. ONCE AGAIN, THANK YOU VERY MUCH FOR YOUR COLLABORATION.

Please indicate in the space below:

Your position in the firm:

Your name:

Your telephone number:

Is there anything else you would like to tell us about the innovation process in your firm? If so, please use the space below for this purpose. 